\title{
A Preliminary Report on the Geology and Gold Deposits of the Rochford District, Black Hills, South Dakota
}

GEOLOG ICAL SURVEY BULLETIN 1332 - A 



\section{A Preliminary Report on the Geology and Gold Deposits of the Rochford District, Black Hills, South Dakota}

By RICHARD W. BAYLEY

CONTRIBUTIONS TO ECONOMIC GEOLOGY

G E O L O G I C A L S U R VE Y B U L L E T I N 1332 -A

The influence of lithology and structure on the gold deposits of the

Rochford district

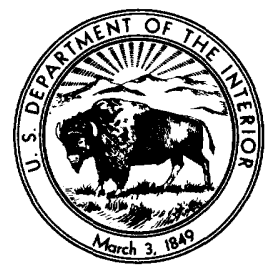


UNITED STATES DEPARTMENT OF THE INTERIOR

WILLIAM P. CLARK, Secretary

\section{GEOLOGICAL SURVEY}

Dallas L. Peck, Director

First printing 1972

Second printing 1983 


\section{CONTENTS}

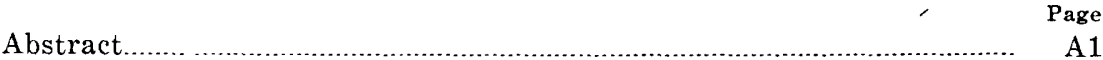

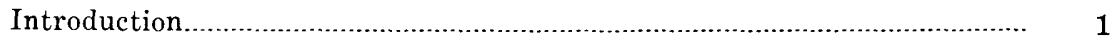

Stratigraphy

Moonshine Gulch Quartzite................................................................. $\quad 3$

Irish Gulch Slate............................................................................... 4

Flag Rock Group ........................................................................ $\quad \mathbf{5}$

Montana Mine and Rochford Formations.................................... $\quad 5$

Rapid Creek Greenstone.......................................................... $\quad 7$

Nahant Schist.........................................................................

Poverty Gulch Slate.......................................................................... 8

Swede Gulch Formation..................................................................... 8

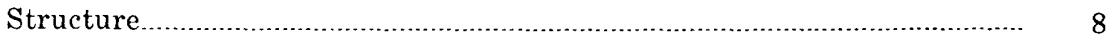

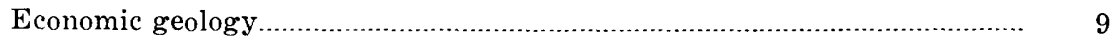

Mines in the Rochford Formation........................................................ 10

Standby mine.................................................................................. 10

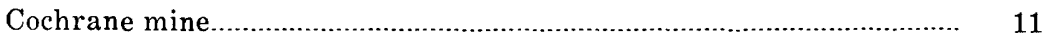

Golden West mine....................................................................... 15

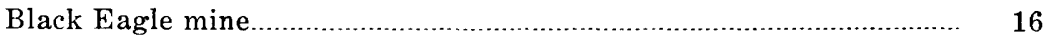

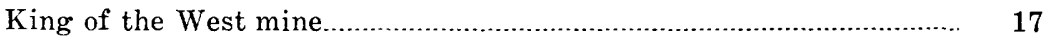

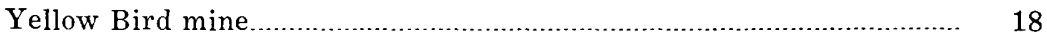

Divide Lode mine........................................................................... 19

Black Tunnel mine.......................................................................... 20

Mary Belle mine............................................................................... 20

Mines in the Montana Mine Formation .................................................. $\quad 20$

Montana mine

Montezuma mine............................................................................ 22

Other prospects of interest................................................................ 24

References cited ...................................................................................... 24

\section{ILLUSTRATIONS}

[Plates are in pocket]

Plate 1. Preliminary geologic map of the Rochford district, Black Hills, South Dakota.

2-4. Sample-locality maps showing:

2. Gold content.

3. Silver content.

4. Arsenic content. 
FIGURE 1. Generalized geologic map of the northern Black Hills,

South Dakota, showing location of Rochford district

2-5. Sketch maps showing:

2. Intervals sampled on pit walls of northern open pit at Standby mine.

3. Sample localities in Cochrane mine open pits in Rochford Formation.

4. Sample localities in Golden West open pit in Rochford Formation.

5. Sample localities on Montana mine anticline.

\section{TABLES}

TABLES 1-5. Chemical analyses of samples from -

1. Standby mine

2. Cochrane mine, October 1968

3. Cochrane mine, 1969

4. Plunging fold at Cochrane mine

5. Golden West mine.

6. King of the West mine.

7. Montana mine. 


\title{
A PRELIMINARY REPORT ON THE GEOLOGY AND GOLD DEPOSITS OF THE ROCHFORD DISTRICT, BLACK HILLS, SOUTH DAKOTA
}

\author{
BY RichaRd W. BAYLEY
}

\section{ABSTRACT}

The Rochford district is an inactive gold camp which lies about 15 miles south of the Lead gold-mining district in the northern Black Hills. Both districts include similar metamorphosed Precambrian formations having complex fold structures. The Rochford district appears to consist chiefly of deep-water sedimentary rocks: quartzites, slates and schists of various sorts, silicated cherty iron-formations, massive cherts, graywackes, pillow basalts, and fragmental volcanic rocks. Deformed dikes of metagabbro and intermediate porphyry are common in the lower part of the rock sequence, and veins of quartz are ubiquitous. The rock formations at Rochford are correlated with those at Lead down to, and including, the Ellison Formation of Hosted and Wright (1923) which, at Lead, rests conformably on the gold-bearing Homestake Formation of Hosted and Wright (1923). The gold-bearing formations at Rochford are the silicated cherty iron-formations which, though younger, closely resemble the Homestake Formation. Gold deposition in both districts seems to have been controlled by the iron-formation lithology and structure. The best deposits are in plunging folds. The principal structure at Rochford is an east-dipping, southeast-plunging anticlinorium flanked by synclinoria. The anticlinoiium apparently extends northward to the area west and northwest of Lead. South of Rochford the anticlinorium bends abruptly to the west and is refolded. The inactive mines are described, and geochemical data for certain mines and the general district are presented. A number of specific localities are reconmended for exploration.

\section{INTRODUCTION}

This report describes briefly the geology and the inactive gold mines of the Rochford district in the northern Black Hills of South Dakota (fig. 1). The district, about 15 miles south of Lead and Deadwood, covers about 69 square miles and is 5,000-6,000 feet above sea level. It is mature hilly terrain, the hills being steep and heavily wooded. Rapid Creek and Castle Creek are the major streams. 
Previous geologic mapping in the district was done by Darton and Paige (1925), Harder (1934), and Allsman (1940). Paige's reconnaissance mapping, though incomplete, is fairly accurate, and he correctly inferred the configuration of the principal structures. The mapping of Harder and Allsman was confined to a very small area (about 1 square mile) east of the town of Rochford. The mapping is of good quality; however, unfortunately, both started with an erroneous stratigraphy which led to incorrect conclusions.

The present mapping program began in 1966. It was primarily intended to explore the northern hills, but the lack of any suitable geologic maps for the region quickly changed the original plan. Geologic mapping began in the Rochford district in 1967 and is being continued concurrently with geochemical sampling. The preliminary geologic map in this report (pl. 1) represents about 8 man-months of fieldwork. Many of the complexities of the map are not wholly understood, but it nevertheless represents the first comprehensive map of the district.

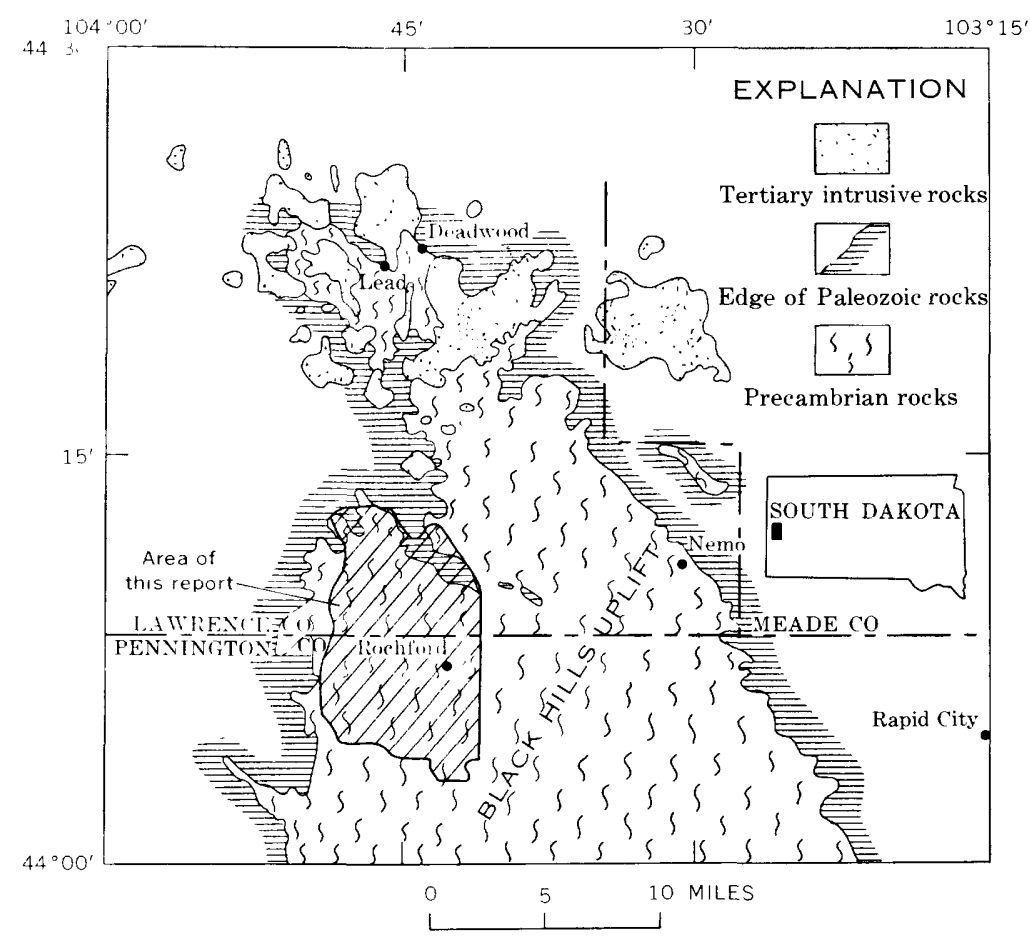

Figure 1. - Generalized geologic map of the northern Black Hills, South Dakota, showing location of Rochford district. 


\section{STRATIGRAPHY}

The principal rocks of the Rochford district are metamorphosed sedimentary and volcanic rocks of middle Precambrian age, less than 2.5 billion years old but more than 1.65 billion years old (Zartman and Stern, 1967). The overall appearance of the rocks suggests that they were deposited in fairly deep water. Representatives of the classic eugeosynclinal suite - graywacke, slate, chert, graphitic slate, and pillow lava - are most abundant. The rock formations in the Rochford district and the corresponding, probably equivalent, formations at Lead are shown below:

Lead and vicinity

Rochford and vicinity

Intrusive metagabbro and intermediate porphyry

Swede Gulch Formation

Slate, graywacke, chert, graphitic slate.

(Dodge, 1942; Noble and Harder, 1948) .. Intrusive metagabbro.

Grizzly Formation.

Poverty Gulch Slate.

Slate, graywacke, chert, graphitic slate.

Garnet slate.

Flag Rock Group.

Rochford Formation.

Chert-grunerite rock.

Nahant Schist.

Graphitic slate and schist.

Rapid Creek Greenstone.

Pillow lava and tuff.

Montana Mine Formation.

Chert-grunerite rock.

Apparent unconformity.

Irish Gulch Slate.

Slate and chert-grunerite rock.

Moonshine Gulch Quartzite

Quartzite and banded slate.

Flag Rock Formation

Graphitic slate, chert,

chert-cummingtonite rock, greenstone.

Unconformity

Northwestern Formation Slate.

Ellison Formation.

Quartzite and schist.

Homestake Formation.

Chert-cummingtonite rock.

Poorman Formation.

Black slate.

The unit descriptions which follow, because they are based on field observations without supporting petrographic data, are subject to minor revisions.

\section{MOONSHINE GULCH QUARTZITE}

A quartzite which closely resembles the Ellison Formation of Hosted and Wright (1923) is herein named the Moonshine Gulch Quartzite. It is the oldest formation exposed in the Rochford district. Moonshine Gulch, in sec. 13, T. 2 N., R. 3 E., is designated the formation's type locality. The quartzite, forming the core of a south-plunging anticline in the northwest, crops out in the east in a wide belt which appears to be the offcenter core of the Rochford anticlinorium. However, the quartzite of the eastern area apparently lacks the typical anticlinal configuration. The fact that all known tops of beds face east suggests that the belt represents a single upright limb of quartzite which either originally lay unconformably beneath the Irish Gulch Slate or was emplaced into the crest of the anticlinorium by faulting.

The formation is composed mainly of dark, nearly black, thickto thin-bedded vitreous quartzite and gray- and black-banded slate. The quartzite shows obvious layering, and thin beds, up to 
2 feet thick, show grain-size gradations which indicate tops of beds; no other primary sedimentary features were observed. The interbedded slates are sericitic to micaceous, and the dark layers are moderately graphitic. Pyrite occurs as disseminated grains in some of the quartzite and as thin deformed flakes in the foliated slate. The formation is cut by numerous sill-like mafic dikes, most of which are extremely schistose and highly altered, mainly to chlorite.

The quartzite is overlain by the Irish Gulch Slate or, where the slate is absent, by the Rapid Creek Greenstone. The contacts appear conformable except in the SW1/4, sec. 13, T. 2 N., R. 3 E., where the Irish Gulch Slate rests discordantly on the Moonshine Gulch Quartzite. The kind of upper contact represented here is uncertain. Strictly on the basis of the slate and greenstone distribution, it could be inferred that both the Irish Gulch Slate and Rapid Creek Greenstone rest unconformably, on the quartzite; however, if the discordance between the quartzite and slate in sec. 13 is regarded as a fault contact, then it could be inferred that the quartzite was faulted into place against the greenstone, thus eliminating the Irish Gulch Slate from the exposed surface. Unfortunately, criteria for determining which of these possibilities is the correct one could not be found. On the basis of the stratigraphic sequence at Lead, it is assumed that the Moonshine Gulch Quartzite is underlain by the Homestake Formation of Hosted and Wright (1923). In 1968 the U.S. Geological Survey drilled a west-trending high-angle hole into the quartzite in Moonshine Gulch (sec. 13) in an attempt to penetrate the Homestake Formation, but the angle of the hole flattened drastically, and drilling was discontinued, still in the quartzite, at a depth of 1,500 feet.

\section{IRISH GULCH SLATE}

The new name Irish Gulch Slate is here applied to a gray to black, sericitic to sparkling micaceous slate without obvious laminae or color banding. Near the base of the formation, close to the underlying Moonshine Gulch Quartzite, there is a single thin chert-grunerite unit that persists along the strike for several miles. This unit is composed of thin contorted beds of sugary ferruginous chert and thin interbeds of silicate minerals, commonly chlorite, various micas, grunerite, and garnet. Typical exposures of Irish Gulch Slate occur on the west side of Irish Gulch, sec. 14, T. 2 N., R. 3 E., designated the type locality, and along Greens Gulch, sec. 2, T. 2 N., R. 3 E., a reference locality.

The Irish Gulch Slate is overlain by the Montana Mine Formation and underlain by the Moonshine Gulch Quartzite. There are 
broad exposures of the Irish Gulch Slate in the central and western parts of the Rochford anticlinorium, but the formation thins drastically to the northwest, thins and pinches out to the southeast, and is absent on the east limb of the anticlinorium. In the area of the pinchout in the SW1/4 sec. 13, T. 2 N., R. 3 E., the Irish Gulch Slate cuts discordantly across the underlying Moonshine Gulch Quartzite, whose nearly vertical beds strike almost perpendicularly to the overlying Irish Gulch Slate. What caused the discordancy between the quartzite, the slate, and the pinchout of the slate has not been resolved, as noted in the previous section. The Irish Gulch Slate is tentatively correlated with the Northwestern Formation as defined by Hosted and Wright (1923) in the Lead sequence, not because of any striking similarity, but because they are both slate formations in apparently the same stratigraphic position.

\section{FLAG ROCK GROUP}

The name Flag Rock Formation was applied by Dodge (1942, p. 563) to a 5,000-foot section of schists and quartzites between the unconformably underlying Northwestern Formation and the overlying Grizzly Formation in the Lead area. No type locality was designated, but Noble and Harder (1948, p. 950) described exposures northeast of Flag Rocks, presumably from which the unit was named.

In the Rochford district, the lower part of this stratigraphic interval is divisible into four distinct formations : two Homestakelike chert-grunerite formations, a volcanic greenstone formation, and a graphitic schist formation. These have been grouped together as the Flag Rock Group in the belief that, collectively, they correlate with the ill-defined multiunit Flag Rock Formation at Lead, which contains approximately similar units that are not in the same sequence.

The relationship of the Flag Rock Group to the overlying Poverty Gulch Slate is simply a conformable one with very localized slight gradations between the adjacent units, whereas the group's relationship to the underlying formations is suggestive of an unconformity, possibly equivalent to the apparent unconformity between the Northwestern Formation and Flag Rock Formation at Lead (Noble and Harder, 1948); however, as noted in the discussion of the Irish Gulch Slate, the apparent unconformity could have developed in other ways.

\section{MONTANA MINE AND ROCHFORD FORMATIONS}

The new names Montana Mine and Rochford Formations are here applied to the stratigraphic units at the base and at the top of 
the Flag Rock Group, respectively. They are discussed together here because they are lithologically similar. The type locality of the Montana Mine Formation is at the Montana mine in sec. 3, T. 2 N., R. 3 E. ; the type locality of the Rochford Formation consists of exposures in secs. 23 and 24, T. 2 N., R. 3 E. in the vicinity of Rochford. The contact of the Montana Mine Formation with the underlying Irish Gulch Slate is sharp. The Montana Mine, overlain by the Nahant Schist or the intervening Rapid Creek Greenstone, is interrupted here and there by intrusive rocks and faults and is absent in a few areas, possibly because of faulting, nondeposition, or erosion prior to the deposition of the overlying formations. The Rochford Formation rests conformably on the Nahant Schist, except in the extreme southeastern part of the area, where the Rochford rests directly on the Rapid Creek Greenstone. It appears everywhere to be overlain conformably by the Poverty Gulch Slate.

The Montana Mine and Rochford Formations, lithologically similar to the chert-grunerite unit at the base of the Irish Gulch Slate and to the Homestake Formation at Lead, are composed predominantly of thick- to thin-bedded ferruginous chert and interlayers of silicate minerals, usually rosettes of grunerite, chlorite, mica, and garnet. The composition of these formations varies from place to place. For example, the Rochford Formation, consisting mainly of chert in the long straight limbs of the anticlinorium, is composed predominantly of rosetted amphibole in the tightly folded areas near its south end.

In the southern part of the anticlinorium, there are excellent roadside exposures of the Rochford Formation which bear a striking resemblance to the Homestake Formation of Hosted and Wright (1923) at Lead. Because of this close resemblance the formation was assumed to be equivalent to the Homestake by Harder (1934) who, with that basic correlation as a starting point, mapped a small area in the vicinity of Rochford as an inverted south-plunging syncline. The inversion of units was based primarily on the fact that at Rochford the so-called Homestake overlies his Ellison Formation (Moonshine Gulch Quartzite of this report), whereas at Lead the type Homestake underlies the Ellison Formation. However, data from the present broader map area show conclusively that the Rochford structure is anticlinal. This finding, in effect, reverses Harder's stratigraphic order and therefore places his so-called Homestake (Rochford Formation of this report) well above the Ellison or Moonshine Gulch Quartzite and within the Flag Rock Group, which is correlated with the type Flag Rock Formation at Lead. 
RAPID CREEK GREENSTONE

The Rapid Creek Greenstone named herein includes three distinct volcanic units which occur in three different areas but at approximately the same stratigraphic horizon. The greenstone pillow lavas east of Rapid Creek in sec. 15, T. 2 N., R. 3 E. are designated the type locality. Exposures of greenstone tuff in secs. 23 and 24 , T. 2 N., R. 3 E., are designated a reference locality. The volcanic rocks are entirely mafic, probably basaltic. Ellipsoidal (pillow) lava occurs on the west limb of the Rochford anticline and in the minor refolded anticlines $21 / 2$ miles south of the town of Rochford, clastic volcanic rocks occupy a northtrending belt which extends through the town of Rochford, and nonellipsoidal mafic lavas are on the east limb of the Rochford anticlinorium overlying the Moonshine Gulch Quartzite. These varieties of volcanic rock are believed to represent the same volcanic episode. The ellipsoidal lavas lie within the Nahant Schist, the volcaniclastic rocks are interbedded with that schist, and the nonellipsoidal lavas underlie the same schist. The lava flows are hard ridge-forming units, dense and massive in most exposures, but schistose locally. In most western exposures the pillows are stretched in torpedolike forms that plunge steeply southward. But pillow cross sections have generally not been greatly distorted by the stretching, and tops of flows may still be determined on most outcrops. The nonellipsoidal lavas on the east limb of the Rochford anticline show no obvious primary volcanic features. Most of the volcaniclastic rocks, probably tuffs and agglomerates originally, have been metamorphosed to pitted brown-weathering calcareous green schist. Though the original clastic texture of the rocks has almost been completely destroyed, the clastic character of the rocks may be observed in an excavation in the slope above the school at Rochford.

\section{NAHANT SCHIST}

The new name Nahant Schist is here applied to slaty to schistose black graphitic rock having no conspicuous bedding. The type locality is at Nahant, sec. 34 , T. 3 N., R. 3 E. At most places the formation lies between the Rapid Creek Greenstone and the Rochford Formation; however, on the west flank of the Rochford anticlinorium it is interbedded with the Rapid Creek Greenstone and rests on the Montana Mine Formation. It appears that the Nahant Schist and Rapid Creek Greenstone were deposited contemporaneously and irregularly and do not conform to the simple layer-cake rule. In the extreme southeastern part of the area, the Nahant Schist is absent, and the Rochford Formation rests on the Rapid Creek Greenstone. 


\section{POVERTY GULCH SLATE}

The Poverty Gulch Slate is here applied to a uniformly darkbrown to black laminated unit in which alternate laminae commonly contain abundant small garnets. This formation is best exposed at its type locality, Poverty Gulch, in sec. 23, T. 2 N., R. 3 E., and along the east side of Silver Creek. It maintains its formational integrity over most of the district, but seems to be interlayered with black graphitic slate in the western part of the district. The Poverty Gulch Slate rests conformably on the Rochford Formation and is overlain in apparent conformity by the Swede Gulch Formation, the lower graphitic part of which probably grades down into the Poverty Gulch Slate.

\section{SWEDE GULCH FORMATION}

The new name Swede Gulch Formation is here applied to a unit composed mainly of schistose argillaceous rocks and graywacke. Typical exposures occur along Swede Gulch in secs. 31, 32 , and 33 , T. 3 N., R. 3 E. The lower part is a graphitic-slate and schist unit which contains or overlies one or two beds of massive streaky ferruginous chert. The upper part, which overlies the Poverty Gulch Slate and is exposed only west of Nahant, is graywacke grit (turbidite) which shows graded beds. This youngest Precambrian formation is the most widespread formation in the northern Black Hills, and, despite its lithologic diversities and the lack of complete exposure, it still provides the best lithologic link between the various districts of the region. The apparently equivalent formation at Lead is called the Grizzly Formation by Dodge (1942) and Noble and Harder (1948).

\section{STRUCTURE}

The principal structure in the Rochford district is an eastdipping isoclinal anticlinorium which trends northwestward and plunges southeastward. It is flanked on the east and west by broad synclinoria. The southern terminus of the central part of the anticlinorium, as defined by the distribution of the Rochford Formation, is complicated in the classical way by eight or more secondary plunging folds and a great many minor folds of lesser orders. The central structure terminates in a plunging anticline in the SW1/4 sec. 25, T. 2 N., R. 3 E. South of this point the anticlinorium is dominated by folds on the flanks of the central structure. Also south of this point the anticlinorium was deformed by a second folding. The anticlinorium in this southern area, as defined by the outer limits of the Poverty Gulch Slate, was bent in a broad arc to the west, and the arc was simultaneously cross- 
folded on northwest axes, thus refolding the original folds of the anticlinorium. This arcuate bending of the anticlinorium affected the synclinorium on the west, which also shows refolding. The fact that most of the refolded folds of the anticlinorium are overturned toward the east and plunge south suggests that the original folds were overturned. The original folding in this area was regional and affected all the rocks of the Black Hills. Secondary folding, which presumably affected the full length of the Black Hills, was probably caused by large-scale right-lateral movement along a fault west of the map area. The faults on plate 1 have all been inferred from the outcrop patterns which, in a few places, show the dislocation, removal, or repetition of certain units. The three faults in the northeast part of plate 1 could be right lateral or normal, upthrown on the west. The fault north of the Cochrane and Balkan mines and the converging north-south fault to the east, in secs. 25 and 36 , were apparently upthrown on the south and east, respectively.

\section{ECONOMIC GEOLOGY}

All the known gold-silver deposits in the Rochford district ware located by prospectors a long time ago, probably between the years 1883 and 1902. That their search was intensively focused on the chert-silicate units, the Rochford and Montana Mine Formations, and the massive ferruginous chert beds near the base of the Swede Gulch Formation indicates an awareness - probably gained from experience in the Lead district - of this particular lithology's gold-bearing potential. Eight or more gold deposits were located and mined, but none were very rich or produced much, and all the mines have long been inactive.

The chert-silicate rocks are oxidized almost everywhere, and the gold-bearing rocks appear to be identical with barren rocks. They must be assayed, therefore, in order to determine whether they contain gold. The results of the geochemical examination are shown graphically on plates 2-4. A comparison of plates 2 and 4 indicates that, as a rule, gold and high arsenic values coincide. This implies a close association between gold and arsenopyrite, which is a common association in most Precambrian gold deposits of the Black Hills. The other sulfides in the mineralized rock are most commonly pyrrhotite and pyrite. In addition to the mineralized chert-silicate rocks, slightly auriferous veins of quartz, apparently containing the same sulfide suite, occur locally, particularly in zones of graphitic schist. The massive ferruginous chert beds near the base of the Swede Gulch Formation are similarly mineralized in many places, but the gold content is common- 
ly very low. Copper oxides occur in the cherts in a number of places, and in a silicified fault zone near the northeast edge of the map area, the oxides occur with galena and minor gold.

One result of the recent geologic mapping is the fitting together of the numerous isolated gold deposits into a comprehensive context (pl. 1). The map shows that all gold deposits which have been mined are in the Rochford and Montana Mine Formations. Therefore, as others have concluded, the chert-silicate lithology appears to have controlled the gold deposition. However, when the geochemical data (pls. 2-4) are combined with the geologic map (pl. 1), a second, less obvious, conclusion may be drawn: within the Rochford and Montana Mine Formations most gold deposits occur in plunging folds. This conclusion is best illustrated by the Standby, Cochrane, Montana, and Montezuma mines. Thus, structure, as well as lithology, controlled goid deposition in the chert-silicate units. This combination, of course, is not unique to the district. It applies equally as well to the Homestake mine at Lead (Slaughter, 1968, p. 1450) and apparently to a number of plunging folds of ferruginous chert in the Galena-Roubaix district (Bayley, 1970). It therefore appears to be a regional phenomenon which may have an important practical application, particularly in the Rochford district where large plunging folds of chert-silicate rocks are very numerous. Moreover, geochemical sampling indicates that nearly all the major folds are at least slightly mineralized in surface exposures. Whether this mineralization increases with depth can only be determined by deep exploration.

\section{MINES IN THE ROCHFORD FORMATION}

Inactive gold mines in the Rochford Formation are the Standby, Cochrane, Golden West, Black Eagle, King of the West, Yellow Bird, Divide Lode, Back Tunnel and Mary Belle.

\section{STANDBY MINE}

The Standby mine is in a contorted plunging syncline in chertgrunerite rock which is cut by a closely spaced swarm of quartz carbonate veins. Hilltop opencuts are connected by a raise to a 1,300-foot adit driven southwest from the mill site. The depth to the adit beneath the opencuts is 425 feet. So-called ore shoots (probably stratigraphic) are 120-160 feet long and 50-100 feet wide and have been followed downward 200 feet (Allsman, 1940). One shoot was cut on the 425-foot level, and Allsman suggests that this may mean that the ore shoots plunge southeastward. Actually, the whole ore formation plunges $60^{\circ}-70^{\circ}$ S.E.; within the ore formation, the depth to which any ore shoot may plunge is controlled only by the depth of the adjacent syncline which, in all 
likelihood, is at least several thousand feet. The tenor of the ore in shoots to the 425 -foot level is best indicated by reported assays because the available production figures do not include gold lost owing to poor recovery. The assays suggest that ore in shoots will average $\$ 6-\$ 10$ per ton at the $\$ 35$ per ounce. The only available production figures were given by Allsman (p. 113) as follows:

\begin{tabular}{|c|c|c|c|c|}
\hline \multirow[b]{2}{*}{ Year } & \multirow{2}{*}{$\begin{array}{c}\text { Ore } \\
\text { (tons) }\end{array}$} & \multicolumn{2}{|c|}{ Gold } & \multirow{2}{*}{$\begin{array}{c}\text { Silver } \\
\text { (ounces) }\end{array}$} \\
\hline & & Value & Ounces & \\
\hline \multirow{3}{*}{\multicolumn{2}{|c|}{$\begin{array}{lr}1893 \ldots \ldots \ldots . . . & 7,000 \\
1894 \ldots \ldots \ldots . .14,700 \\
1908 \ldots \ldots \ldots \ldots . & 800 \\
1909 \ldots \ldots \ldots \ldots . & 1,500\end{array}$}} & $\begin{array}{r}\$ 15,000 \\
51,450\end{array}$ & $\ldots \ldots .$. & $\cdots$ \\
\hline & & ……. & 69.38 & 15 \\
\hline & & .......... & 107.15 & 99 \\
\hline
\end{tabular}

Milling was by stamp amalgamation and recovery was unsatisfactory.

Samples were collected in the northernmost open pit (fig. 2) by chipping bed by bed along the wall of the pit. Each sample was small, probably not over 1 pound, and usually represented 2-4 feet of beds. See table 1 for chemical analyses.

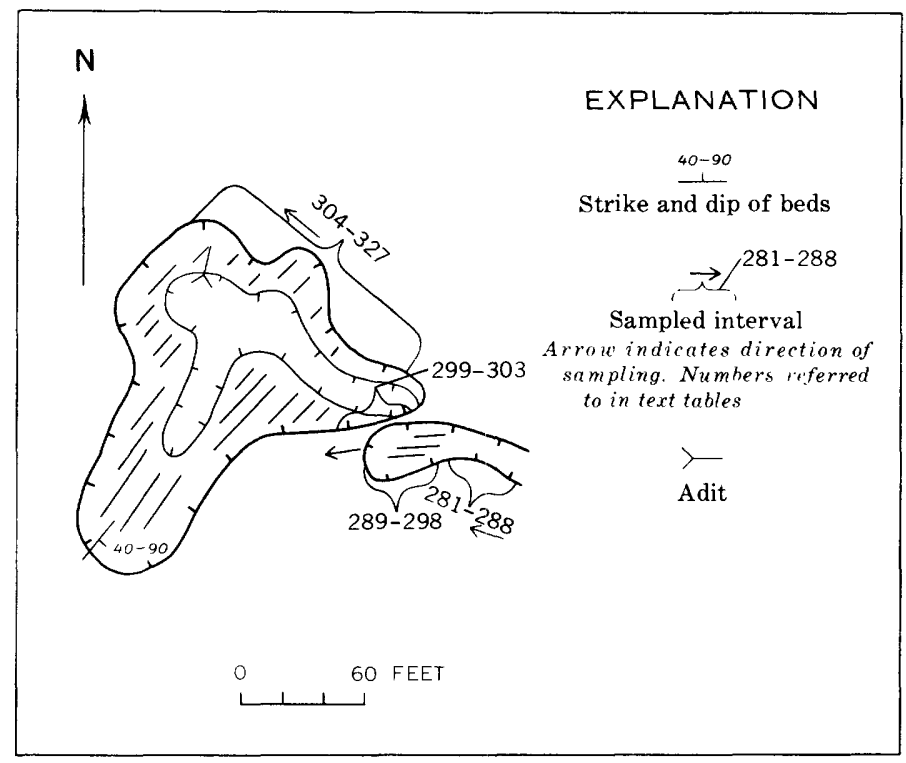

Figure 2. - Intervals sampled on pit walls of northern open pit at Standby mine.

COCHRANE MINE

The Cochrane mine, in the SW1/4 sec. 26, T. 2 N., R. 3 E., consists of several fairly large open pits and several shafts, the deepest shaft reportedly being 100 feet. The pits are in oxidized chert-grunerite rocks of the Rochford Formation in the plunging overturned crest of a narrow anticline. The formation is corrugated by minor folds which plunge almost $80^{\circ} \mathrm{E}$. The mine was 
located about 1883 and last operated in about 1936 (U.S. Bur. Mines, 1954). Nine samples were taken from west to east across the south face of the middle open pit (fig. 3) in the chertgrunerite rock. See table 2 for chemical analyses.

The Cochrane mine was sampled again in 1969. Sample localities are shown in figure 3 , a rough field sketch of the southern part of the mine area. See table 3 for chemical analyses.

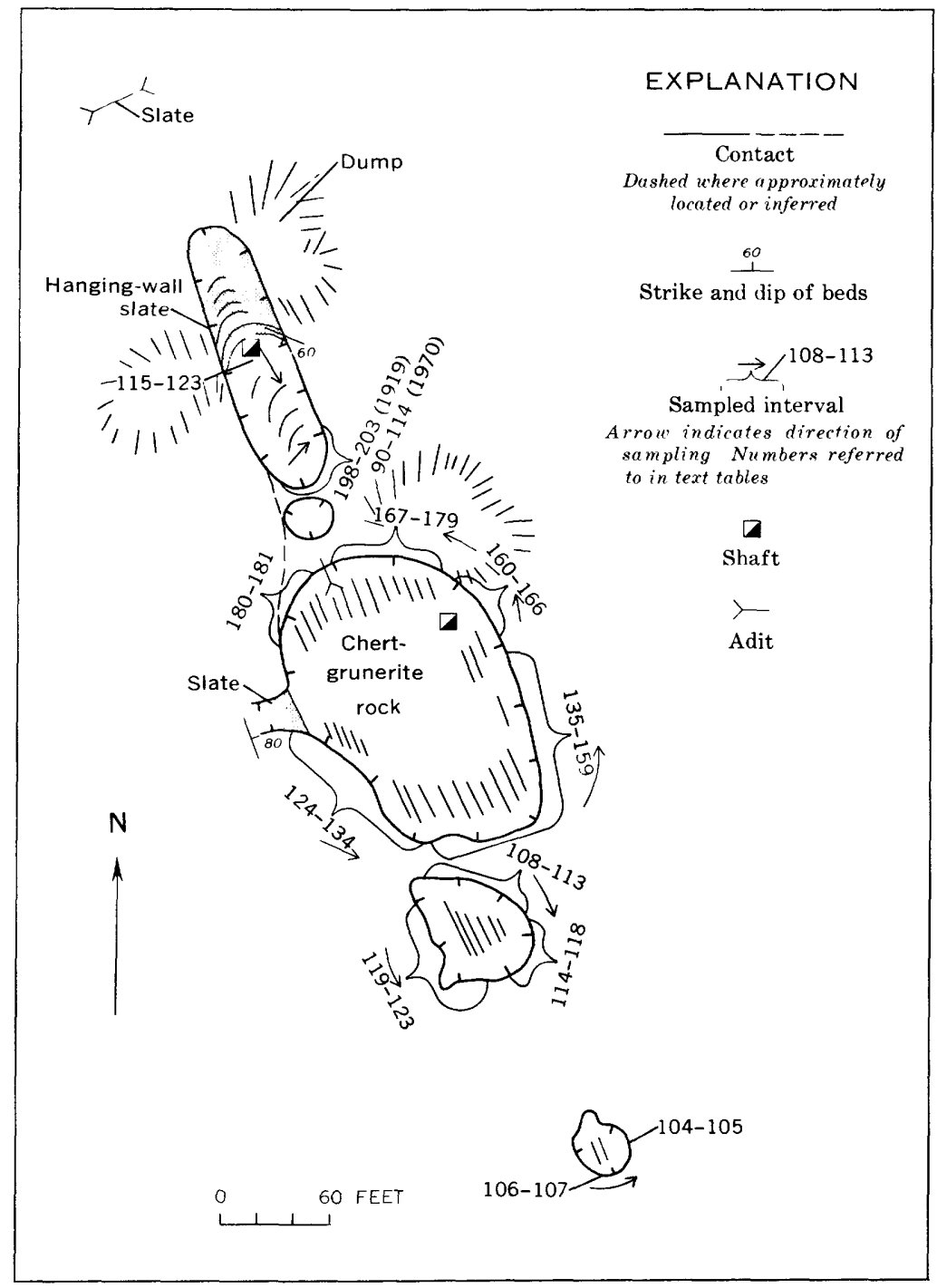

FIgURE 3. - Sample localities in Cochrane mine open pits in Rochford Formation. 
TABLE 1. - Chemical analyses, in parts per million, of samples from the Standby mine

\begin{tabular}{|c|c|c|c|c|c|c|c|}
\hline Sample & $\mathrm{Au}$ & $\mathrm{Cu}$ & As & Sample & $\mathrm{Au}$ & $\mathrm{Cu}$ & As \\
\hline $281 \ldots \ldots \ldots$ & 0.10 & $\cdots$ & 150 & $304 \ldots \ldots$ & 1.00 & 13 & 120 \\
\hline $282 \ldots \ldots \ldots$ & .30 & $\ldots$. & 80 & $305 \ldots \ldots \ldots$ & .20 & .... & 100 \\
\hline $283 \ldots \ldots$ & .05 & $\ldots$ & 80 & $306 \ldots \ldots \ldots$ & 2.80 & .... & 120 \\
\hline $284 \ldots$ & .08 & .... & 40 & 307 & .50 & $\ldots$. & 150 \\
\hline $285 \ldots$ & .20 & $\ldots$. & 20 & $308 \ldots \ldots$ & 1.10 & .... & 150 \\
\hline $286 \ldots \ldots$ & .30 & $\ldots$. & 40 & $309 \ldots \ldots \ldots$ & .04 & .... & 200 \\
\hline $287 \ldots \ldots . . . .$. & .02 & $\ldots$. & 40 & $310 \ldots \ldots \ldots$ & 7.30 & $\ldots$. & 120 \\
\hline $288 \ldots \ldots$ & .06 & & 10 & $311 \ldots \ldots \ldots$ & 2.00 & & 800 \\
\hline & & & & $312 \ldots \ldots \ldots$ & 3.50 & 12 & 1,000 \\
\hline $289 \ldots$ & .10 & $\cdots$ & 150 & $313 \ldots \ldots \ldots$ & 4.30 & 10 & 1,200 \\
\hline $290 \ldots$ & .40 & $\ldots$. & 120 & $314 \ldots \ldots \ldots$ & 1.70 & 15 & 1,000 \\
\hline $291 \ldots$ & .06 & $\ldots$. & 20 & $315 \ldots$ & .80 & 15 & 800 \\
\hline $292 \ldots \ldots$ & .02 & & 80 & $316 \ldots \ldots$ & 1.30 & 10 & 1,000 \\
\hline $293 \ldots \ldots$ & 1.60 & 18 & 600 & $317 \ldots$ & 3.80 & 17 & 150 \\
\hline $294 \ldots \ldots . .$. & 5.00 & 15 & 750 & $318 \ldots$ & 5.50 & 10 & 600 \\
\hline $295 \ldots \ldots$ & .50 & 11 & 300 & $319 \ldots$ & 3.00 & 10 & 800 \\
\hline 296 & 5.00 & 12 & 150 & 320 & 10.00 & 15 & 1,200 \\
\hline $297 \ldots \ldots \ldots$ & 1.80 & & 80 & $321 \ldots \ldots \ldots$ & 2.20 & 15 & 2,000 \\
\hline $298 \ldots \ldots$ & .10 & 15 & 100 & $322 \ldots$ & 3.50 & $\ldots$ & 1,200 \\
\hline & & & & $323 \ldots .$. & 1.40 & & 1,600 \\
\hline $299 \ldots \ldots$. & 1.80 & 15 & 300 & $324 \ldots \ldots$ & 1.00 & 15 & 800 \\
\hline $300 \ldots \ldots$ & 7.20 & & 300 & $325 \ldots$ & .70 & .... & 800 \\
\hline $301 \ldots \ldots$ & 38.00 & 18 & 300 & $326 \ldots$ & .20 & $\ldots$. & 600 \\
\hline $302 \ldots \ldots$ & 1.9 & 10 & 120 & $327 \ldots \ldots \ldots$ & .60 & .... & 600 \\
\hline $303 \ldots \ldots \ldots$ & .16 & $\ldots$ & 40 & & & & \\
\hline
\end{tabular}

TABLE 2. - Chemical analyses, in parts per million, of samples from the Cochrane mine, October 1968

\begin{tabular}{|c|c|c|c|c|}
\hline Sample & & $\mathrm{Au}$ & $\mathrm{Ag}$ & $\mathrm{Cu}$ \\
\hline RB-650-68 & & 0.10 & 4.2 & 110 \\
\hline 651 & ….......... & .10 & 2.2 & 100 \\
\hline 652 & . & .06 & .6 & $<10$ \\
\hline 653 & ….................. & 3.50 & 3.0 & 160 \\
\hline 654 & 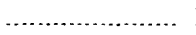 & 16.00 & 2.6 & \\
\hline 655 & 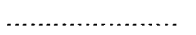 & 1.30 & 3.4 & \\
\hline 656 & ‥-1, & .20 & 2.0 & \\
\hline 657 & ……… & .04 & 1.0 & \\
\hline 658 & & 13.00 & 6.0 & 100 \\
\hline
\end{tabular}

The analyses indicate that the entire formation is anomalously rich in gold. Only careful three-dimensional sampling will show if the richer zones possess the necessary continuity and bulk. The ore shoots, if any, will plunge eastward but, because of the overturned anticlinal structure, must turn westward at some depth. An exception to the assumed eastward plunge is shown by the southeast-plunging inverted anticlinal roll in the north pit (fig. 3). The values for samples RB-167-69-RB-179-69 and RB-198-69-RB-203-69 in table 3 suggest that this plunging structure may also be a plunging ore body of considerable interest. Detailed, bed by bed, sampling was done across this plunging structure in 1970. See table 4 for chemical analyses.

The following data from Allsman (1940) are the only production records for the Cochrane mine:

\begin{tabular}{cccc}
\hline Year & $\begin{array}{c}\text { Ore milled } \\
\text { (tons) }\end{array}$ & $\begin{array}{c}\text { Gold } \\
\text { (ounces) }\end{array}$ & $\begin{array}{c}\text { Silver } \\
\text { (ounces) }\end{array}$ \\
\hline $1904 \ldots \ldots \ldots \ldots$. & 70 & 15 & $\ldots$. \\
$1905 \ldots \ldots \ldots \ldots$. & 93 & 19.35 & $\ldots$. \\
$1916 \ldots \ldots \ldots \ldots$ & 300 & 84.22 & 54 \\
$1931 \ldots \ldots \ldots \ldots$. & 162 & 81.06 & 55 \\
$1932 \ldots \ldots \ldots \ldots$. & 150 & 24.91 & 18 \\
$1936 \ldots \ldots \ldots \ldots .4,200$ & 128.37 & 86 \\
\hline
\end{tabular}


It appears from this record that only exploration and development were done and that in 1936, the last year of operation, everything that came out of the pits, waste rock and all, was put through the mill and amalgamated, probably with poor recovery.

TABLE 3. - Chemical analyses, in parts per million, of samples from the Cochrane mine, 1969

\begin{tabular}{|c|c|c|c|c|c|c|c|c|c|c|}
\hline Sample & $\mathrm{Au}$ & $\mathrm{Ag}$ & $\mathrm{Cu}$ & As & Sample & & $\mathrm{Au}$ & Ag & $\mathrm{Cu}$ & As \\
\hline RB-104-6 & $9 \ldots \ldots \ldots . .04$ & 1.40 & 140 & 40 & RB-147-69 & (............... & $<0.02$ & 1.40 & 53 & \\
\hline 105 & $\ldots \ldots \ldots \ldots<<.02$ & 1.40 & 27 & & 148 & & $<.02$ & 2.20 & 60 & 20 \\
\hline 106 & ……...... .02 & 1.20 & 13 & 20 & 149 & …….... & 1.90 & 2.00 & 110 & 40 \\
\hline 107 & .04 & 1.40 & 29 & 20 & 150 & ............ & 1.70 & 2.00 & 53 & .... \\
\hline & & & & & 151 & ............ & 2.80 & 2.40 & 77 & $\cdots$ \\
\hline 108 & $\ldots \ldots \ldots<<.02$ & .80 & 10 & 150 & 152 & ……..... & 3.60 & 3.00 & 28 & .... \\
\hline $\begin{array}{l}109 \\
110\end{array}$ & …........ & 1.00 & 21 & 1,000 & 153 & $+\ldots+\ldots . .$. & .10 & 1.00 & & \\
\hline 110 & $\ldots \ldots<<<.02$ & 1.40 & 58 & 5,000 & 154 & ….......... & .08 & 1.20 & 27 & 10 \\
\hline 111 & $\ldots \ldots \ldots \ldots<<.02$ & 2.00 & 90 & 100 & 155 & ……..... & .08 & 1.40 & 38 & 10 \\
\hline 112 & ................... & 1.00 & 75 & 4,000 & 156 & .............. & .10 & 1.60 & 47 & 20 \\
\hline 113 & $<-1.02$ & 1.40 & 75 & 100 & 157 & .............. & .04 & 1.20 & 54 & \\
\hline 114 & $\ldots \ldots \ldots \ldots<.02$ & .60 & 10 & 100 & 158 & ……..... & .04 & 1.60 & 53 & 10 \\
\hline 115 & $\begin{array}{ll}. \ldots \ldots \ldots \ldots \ldots \\
\ldots \ldots \ldots \ldots\end{array}$ & 1.20 & 40 & 800 & 159 & ….......... & .02 & 1.40 & .... & $\cdots$ \\
\hline 116 & 6.40 & 2.40 & 50 & 1,200 & & & & & & \\
\hline 117 & $\begin{array}{l}\text {............. } \\
0\end{array}$ & .80 & 24 & 150 & 160 & ……...... & 2.40 & 1.80 & 29 & 500 \\
\hline 118 & …........ 1.40 & 1.20 & 46 & 120 & 161 & ……...... & 1.10 & 1.60 & 52 & 100 \\
\hline 119 & ………... $\quad .50$ & 1.60 & 65 & 1,500 & 162 & ……..... & .46 & 1.00 & 25 & 100 \\
\hline 120 & ……- 3.50 & 1.40 & 63 & 150 & 163 & ……...... & 10.00 & 1.20 & 33 & 80 \\
\hline 121 & $\ldots \ldots \ldots \ldots<<.02$ & 2.80 & 350 & 100 & 164 & ............. & .04 & 1.40 & 10 & 20 \\
\hline 122 & $\ldots \ldots \ldots<<.02$ & .80 & 42 & 80 & 165 & ……...... & .50 & 3.00 & 82 & 200 \\
\hline 123 & $<.02$ & 1.40 & 90 & 150 & 166 & .............. & 1.20 & 1.60 & 65 & 120 \\
\hline 124 & $\ldots \ldots<<<.02$ & 1.00 & 10 & 50 & 167 & ............ & .10 & 1.80 & 40 & 200 \\
\hline 125 & $\ldots \ldots \ldots<<.02$ & 2.20 & 105 & 100 & 168 & ……...... & 10.00 & 3.80 & 70 & 800 \\
\hline 126 & $\ldots<<<<02$ & 1.60 & 60 & 150 & 169 & ............. & .60 & 2.00 & 67 & 1,500 \\
\hline 127 & $\ldots \ldots \ldots<<.02$ & .80 & 42 & 100 & 170 & .......... & 18.00 & 2.00 & 46 & 80 \\
\hline 128 & $\ldots \ldots \ldots \ldots<<.02$ & 1.20 & 57 & 120 & 171 & .......... & 2.00 & 2.40 & 74 & 100 \\
\hline 129 & $\ldots \ldots \ldots<.02$ & 1.20 & 64 & 10 & 172 & ............. & .14 & 1.20 & 20 & 20 \\
\hline 130 & .02 & 2.20 & 120 & 50 & $17 \overline{3}$ & …….... & 10.00 & 3.00 & 40 & 120 \\
\hline 131 & ……........ & 2.00 & 190 & 100 & 174 & ......... & .60 & 1.20 & 31 & 40 \\
\hline 132 & ………... & 2.00 & 81 & 1,000 & 175 & ............. & 3.20 & 3.00 & 38 & 150 \\
\hline 133 & ……..... & 2.00 & 120 & 1,200 & 176 & ........ & 3.60 & 6.00 & 54 & 150 \\
\hline 134 & ……...... $\quad .04$ & 2.40 & 130 & 10,000 & 177 & …….... & 16.00 & 15.00 & 74 & 1,200 \\
\hline 135 & ……….... & 1.80 & 83 & 4,000 & 178 & ............. & .40 & 14.00 & 120 & 1,200 \\
\hline 136 & ............. .80 & 3.20 & 110 & 8,000 & 179 & ............ & 1.00 & 9.00 & 140 & 150 \\
\hline 137 & …….... 2.10 & 3.20 & 120 & 1,500 & & & & & & \\
\hline 138 & 4.40 & 2.20 & 85 & 800 & 180 & $\ldots \ldots$ & .10 & 2.60 & 110 & 150 \\
\hline 139 & .08 & 1.60 & 70 & 100 & 181 & ............ & .10 & 2.40 & 82 & 200 \\
\hline 140 & ........... 1.80 & 1.60 & 68 & 50 & & & & & & \\
\hline 141 & ............. .02 & 1.20 & 42 & 10 & 198 & ........... & 7.00 & 1.40 & 26 & 300 \\
\hline & & & & & 199 & ...... & 8.50 & 4.00 & & \\
\hline 142 & $\ldots \ldots \ldots<.02$ & 1.0 & 39 & 30 & 200 & …..... & 20.00 & 3.80 & 42 & 300 \\
\hline 143 & … 32.00 & 2.40 & 50 & & 201 & ……...... & 20.00 & 5.00 & 55 & 100 \\
\hline 144 & ……......... .80 & 1.40 & 90 & 40 & 202 & ........... & 14.00 & 3.60 & 50 & 1,000 \\
\hline 145 & ……...... .20 & 1.20 & 19 & $\ldots$ & 203 & .............. & 7.00 & 3.00 & 50 & 900 \\
\hline 146 & $\ldots \ldots \ldots \ldots<<.02$ & 1.40 & & $\cdots$ & & & & & & \\
\hline
\end{tabular}

TABLE 4. - Chemical analyses, in parts per million, of samples from plunging fold at Cochrane mine

[Samples collected from west to east across open pits]

\begin{tabular}{|c|c|c|c|c|c|c|c|c|}
\hline Sample & Ag & $\mathrm{Cu}$ & As & Sample & $\mathrm{Au}$ & $\mathrm{Ag}$ & $\mathrm{Cu}$ & As \\
\hline \multicolumn{4}{|c|}{ South pit } & \multicolumn{5}{|c|}{ South pit - Continued } \\
\hline $90 \ldots \ldots \ldots \ldots$ & 25.0 & 80 & 20 & 110. & 3.0 & 1.5 & 35 & 150 \\
\hline $91 \ldots \ldots \ldots \ldots .120 .0$ & 15.0 & 45 & 100 & $111 \ldots$ & 2.0 & 2.5 & 35 & $<10$ \\
\hline $92 \ldots$ & 9.5 & 45 & 100 & $112 \ldots \ldots$ & .2 & 1.0 & 35 & 80 \\
\hline 93 & 9.0 & 45 & $<10$ & $113 \ldots \ldots$ & .1 & 1.0 & 15 & $<10$ \\
\hline $94 \ldots \ldots \ldots \ldots$ & 6.0 & 50 & 80 & $114 \ldots \ldots$ & .1 & 1.0 & 5 & $<10$ \\
\hline $95 \ldots \ldots \ldots \ldots$ & 3.0 & 35 & 10 & \multicolumn{5}{|c|}{ North pit } \\
\hline $96 \ldots \ldots \ldots \ldots$ & 2.0 & 25 & $<10$ & & & & & 500 \\
\hline $97 \ldots \ldots \ldots \ldots \ldots$ & 3.5 & 45 & 60 & $115 \ldots \ldots$ & 0.4 & $\begin{array}{l}5.5 \\
3.5\end{array}$ & $\begin{array}{l}80 \\
65\end{array}$ & $\begin{array}{l}500 \\
200\end{array}$ \\
\hline $98 \ldots \ldots \ldots \ldots \ldots$ & 1.0 & 45 & 150 & $116 \ldots \ldots$ & 86.0 & $\begin{array}{l}3.5 \\
2.5\end{array}$ & 40 & $<10$ \\
\hline $99 \ldots \ldots \ldots \ldots \ldots$ & 5.0 & 55 & 100 & $117 \ldots \ldots$ & $\begin{array}{r}80.0 \\
6.0\end{array}$ & $\begin{array}{l}2.0 \\
1.0\end{array}$ & $\begin{array}{l}40 \\
40\end{array}$ & 150 \\
\hline $100 \ldots \ldots \ldots \ldots$ & 2.5 & 85 & 150 & $118 \ldots \ldots$ & 10.0 & 2.0 & $\begin{array}{l}40 \\
50\end{array}$ & $<10$ \\
\hline $101 \ldots \ldots \ldots \ldots$ & 2.5 & 70 & 300 & $119 \ldots \ldots$ & 2.0 & 2.0 & 45 & 10 \\
\hline $102 \ldots \ldots \ldots \ldots$ & 1.5 & 25 & 10 & $120 \ldots \ldots$ & 80.0 & $\begin{array}{l}2.5 \\
3.5\end{array}$ & 20 & 80 \\
\hline $103 \ldots \ldots \ldots \ldots$ & 1.5 & 30 & 150 & $121 \ldots \ldots$ & 20.0 & 2.0 & 40 & 200 \\
\hline $104 \ldots \ldots \ldots \ldots .40 .0$ & 7.5 & 100 & 300 & $122 \ldots \ldots$ & $\begin{array}{r}20.0 \\
4.0\end{array}$ & 10.0 & 40 & 150 \\
\hline $105 \ldots \ldots \ldots \ldots$ & 5.5 & 65 & 150 & & & & & \\
\hline 106 & 6.5 & 20 & 150 & & & & & \\
\hline $107 \ldots \ldots \ldots \ldots 100$ & 7.5 & 80 & 150 & & & & & \\
\hline $108 \ldots \ldots \ldots \ldots 130.0$ & 20.0 & 130 & 40 & & & & & \\
\hline $109 \quad \ldots \ldots \ldots \ldots$ & 7.5 & 110 & 150 & & & & & \\
\hline
\end{tabular}


GOLDEN WEST MINE

The Golden West mine, in the NW1/4 sec. 3, T. 1 N., R. 3 E., operated from 1902 to about 1908. Mining was underground until about 1905 , then by opencut to a depth of about 35 feet. The ore was moved by an aerial tramway to a mill on Castle Creek. An opencut and a shallow shaft are visible today. The opencut is in a belt of chert-grunerite rock about 200 feet wide. The rock is plicated by minor folds and is cut by a conspicuous set of joints that dip north at low angles. In the vicinity of the shaft, the joint surfaces are covered with massive pyrrhotite several inches thick. This heavy sulfide zone appears to be about 20-35 feet wide and about 22 feet thick and probably plunges $10^{\circ}-12^{\circ} \mathrm{NW}$. Analyses (Allsman, 1940) indicate that the upper 10 feet of the shaft was in the ore zone; the lower 20 feet was not. According to Allsman, a small caved shaft east of the opencut was probably in the sulfide zone at a depth of 20 feet. The visible workings do not indicate that the mineralized zone was ever followed northwestward. However, Allsman (p. 118) reported that 15 holes were drilled to a depth of 150 feet, although he did not give locations and results. Sampling results (p. 120) indicate that the average gold value for ore in the sulfide zone is approximately $\$ 10.50$ per ton at $\$ 35$ per ounce. Allsman stated that the sulfide minerals in the ore zone are 20-25 percent pyrrhotite and 1/2-1 percent arsenopyrite, that the gold is principally associated with the arsenopyrite, and that gold can be recovered satisfactorily by flotation.

The ore zone is in the crest of a narrow overturned anticline in the Rochford Formation, both limbs of which dip $80^{\circ}-85^{\circ} \mathrm{E}$. This formation and the overlying ones are generally not magnetic, but the ore zone is, owing to the pyrrhotite. Magnetometer traverses northeast of the opencut indicate that the pyrrhotite body extends in that direction about 1,200 feet. However, a broader survey is needed to determine if other similar magnetic bodies occur in the general area.

Production from the Golden West mine is as follows (Allsman, 1940, p. 118) :

\begin{tabular}{lrcc}
\hline Year & $\begin{array}{c}\text { Ore } \\
\text { (tons) }\end{array}$ & $\begin{array}{c}\text { Gold } \\
\text { (ounces) }\end{array}$ & $\begin{array}{c}\text { Silver } \\
\text { (ounces) }\end{array}$ \\
\hline 1902 & 500 & 120.93 & $\ldots$. \\
$1903 \ldots \ldots \ldots \ldots \ldots . . .1,300$ & 251.00 & $\ldots \ldots$ \\
$1905 \ldots \ldots \ldots \ldots .10,000$ & 580.50 & 119 \\
$1906 \ldots \ldots \ldots \ldots$ & 5,835 & 349.99 & 118 \\
$1907 \ldots \ldots \ldots \ldots$. & 287 & 55.49 & 21 \\
\hline
\end{tabular}

These figures indicate that ore was mined selectively in 1902, 1903 , and 1907 , and the yield was $\$ 6.70-\$ 8.40$ per ton. Apparently, in 1905 and 1906 mining was by open pit, and thousands of tons of low-grade ore were pushed through the mill, thereby lowering the average gold value to about $\$ 2.00$ per ton. Doubtless, some of 
the ore was unoxidized and probably gave poor recovery. Tailings remaining at the mill, estimated to be 3,100 tons in 1932, reportedly average $\$ 2.10$ per ton (p. 120). The Golden West was sampled in 1971. One sample of oxidized pyrrhotite from the open pit assayed $\$ 5.40$ in gold per ton. The open pit is shown in figure 4 , and the analyses in table 5.

TABLE 5. - Chemical analyses, in parts per million, of samples from Golden West mine

\begin{tabular}{|c|c|c|c|c|c|c|c|}
\hline Sample & $\mathrm{Au}$ & $\mathrm{Ag}$ & As & Sample & $\mathrm{Au}$ & $\mathrm{Ag}$ & $\mathrm{As}$ \\
\hline $132 \ldots \ldots \ldots \ldots \ldots 00$ & 0.32 & $<0.5$ & 40 & $164 \ldots \ldots$ & 0.30 & 0.5 & 120 \\
\hline 133 & .06 & & $<10$ & $165 \ldots \ldots$. & .78 & 1.5 & 240 \\
\hline $134 \ldots$ & .10 & $<.5$ & 20 & $166 \ldots \ldots$ & 1.10 & .5 & 120 \\
\hline 135 & .12 & .5 & 20 & 167 & 3.20 & 1.0 & 200 \\
\hline $136 \ldots \ldots$ & .10 & .5 & 80 & $168 \ldots \ldots \ldots$ & 1.30 & .5 & 120 \\
\hline 137 & .54 & .5 & 20 & 169 & .74 & .5 & 120 \\
\hline $138 \ldots \ldots$ & .12 & .5 & 10 & $170 \ldots \ldots$ & .90 & .5 & 80 \\
\hline 139 & .08 & .5 & 10 & $171 \ldots \ldots$ & 3.10 & .5 & $<10$ \\
\hline $140 \ldots \ldots \ldots \ldots$ & .08 & 1.0 & 10 & $172 \ldots \ldots \ldots$ & 1.90 & .5 & 20 \\
\hline $141 \ldots \ldots \ldots \ldots \ldots \ldots \ldots$ & .42 & .5 & 20 & $173 \ldots \ldots$ & .66 & .5 & 40 \\
\hline 142 & .06 & $<.5$ & 10 & $174 \ldots \ldots$ & 1.70 & .5 & 80 \\
\hline 143 & .12 & .5 & $<10$ & $175 \ldots \ldots$ & 1.50 & .5 & 160 \\
\hline $144 \ldots \ldots \ldots \ldots$ & .14 & .5 & $<10$ & $176 \ldots \ldots$ & .70 & 1.0 & 60 \\
\hline $145 \ldots \ldots \ldots \ldots \ldots \ldots$ & .12 & .5 & 10 & 177 & 4.10 & .5 & 80 \\
\hline $146 \ldots$ & .08 & .5 & 40 & $178 \ldots$ & 1.90 & .5 & 80 \\
\hline $147 \ldots \ldots \ldots \ldots \ldots \ldots \ldots$ & .26 & 1.0 & 10 & $179 \ldots \ldots$ & 1.30 & .5 & 120 \\
\hline $148 \quad \ldots \ldots \ldots \ldots \ldots . . .1$ & 1.7 & 1.0 & 40 & $180 \ldots \ldots$ & 2.20 & 1.0 & 40 \\
\hline $149 \ldots \ldots \ldots \ldots$ & .10 & .5 & 10 & $181 \ldots \ldots$ & 1.40 & .5 & 10 \\
\hline $150 \ldots \ldots \ldots \ldots \ldots \ldots \ldots \ldots \ldots \ldots \ldots \ldots \ldots$ & .10 & 1.0 & 10 & $182 \ldots \ldots \ldots$ & .86 & .5 & 40 \\
\hline $151 \ldots \ldots \ldots \ldots \ldots$ & .18 & 1.0 & 20 & $183 . \ldots$. & 1.00 & 1.0 & 10 \\
\hline $152 \ldots \ldots$ & .56 & 1.0 & 80 & $184 . \ldots$. & .08 & 1.0 & 20 \\
\hline 153 & 4.40 & 1.5 & $<10$ & $185 \ldots \ldots$ & .62 & 1.0 & 120 \\
\hline $154 \ldots \ldots \ldots$ & .94 & .5 & 80 & $186 \ldots \ldots$ & .38 & 5.0 & 2,000 \\
\hline 155 & 1.60 & .0 & 300 & $187 \ldots \ldots$ & .84 & 2.5 & 1,500 \\
\hline 156 & 4.00 & 1.0 & 200 & $188 \ldots \ldots$ & 2.70 & 1.5 & 1,500 \\
\hline $157 \ldots \ldots$ & 7.20 & 1.5 & 160 & $189 \ldots \ldots$ & .64 & & \\
\hline $158 \ldots \ldots \ldots \ldots \ldots 11$ & 1.00 & 2.5 & 200 & $190 \ldots \ldots$ & .74 & 2.0 & 200 \\
\hline $159 \ldots \ldots$ & .10 & .5 & 10 & $191 \ldots \ldots$ & 21.00 & 1.5 & 240 \\
\hline 160 & 1.70 & 1.5 & 40 & $192 \ldots$ & 1.00 & 5.0 & 1,000 \\
\hline $161 \ldots \ldots$ & .40 & .5 & 40 & $193 \ldots \ldots$ & 3.00 & 2.5 & 1,000 \\
\hline $162 . \ldots \ldots \ldots \ldots$ & .12 & .5 & 40 & $194 \ldots \ldots$ & 16.00 & 2.0 & 240 \\
\hline $163 \ldots \ldots \ldots \ldots \ldots$ & 2.20 & .5 & 1,000 & & & & \\
\hline
\end{tabular}

BLACK EAGLE MINE

The Black Eagle mine is in the SE1/4 sec. 33, T. 2 N., R. 3 E., north of the Golden West mine and on the same anticlinal belt of Rochford Formation. The mine workings seem to have been in the trough and along the west limb of a plunging synclinal fold. Records show that the mine consisted of five shafts which were 75-120 feet deep, an 800-foot adit, and 400-500 feet of drifts and crosscuts. Mining began in 1897 and ended in 1904. Ore mined prior to 1904 was milled at the Montezuma mill at Rochford, and no record of the recovery is available. Ore mined in 1904 was put through a new 50-ton Huntington mill on the property; $\$ 1,240.00$ in gold and $\$ 35.00$ in silver were extracted from 606 tons of ore. Despite the unimpressive history of the Black Eagle, the fold couple in this area well deserves further investigation because it is just such structures, particularly the western anticlinal parts, that are most often ore bearing. Many surface pits have already been dug. A magnetic survey should now be conducted to locate any pyrrhotite concentrations, and the anticlinal crest, which plunges S. $58^{\circ}$ E. at about $45^{\circ}$, should then be drilled. 


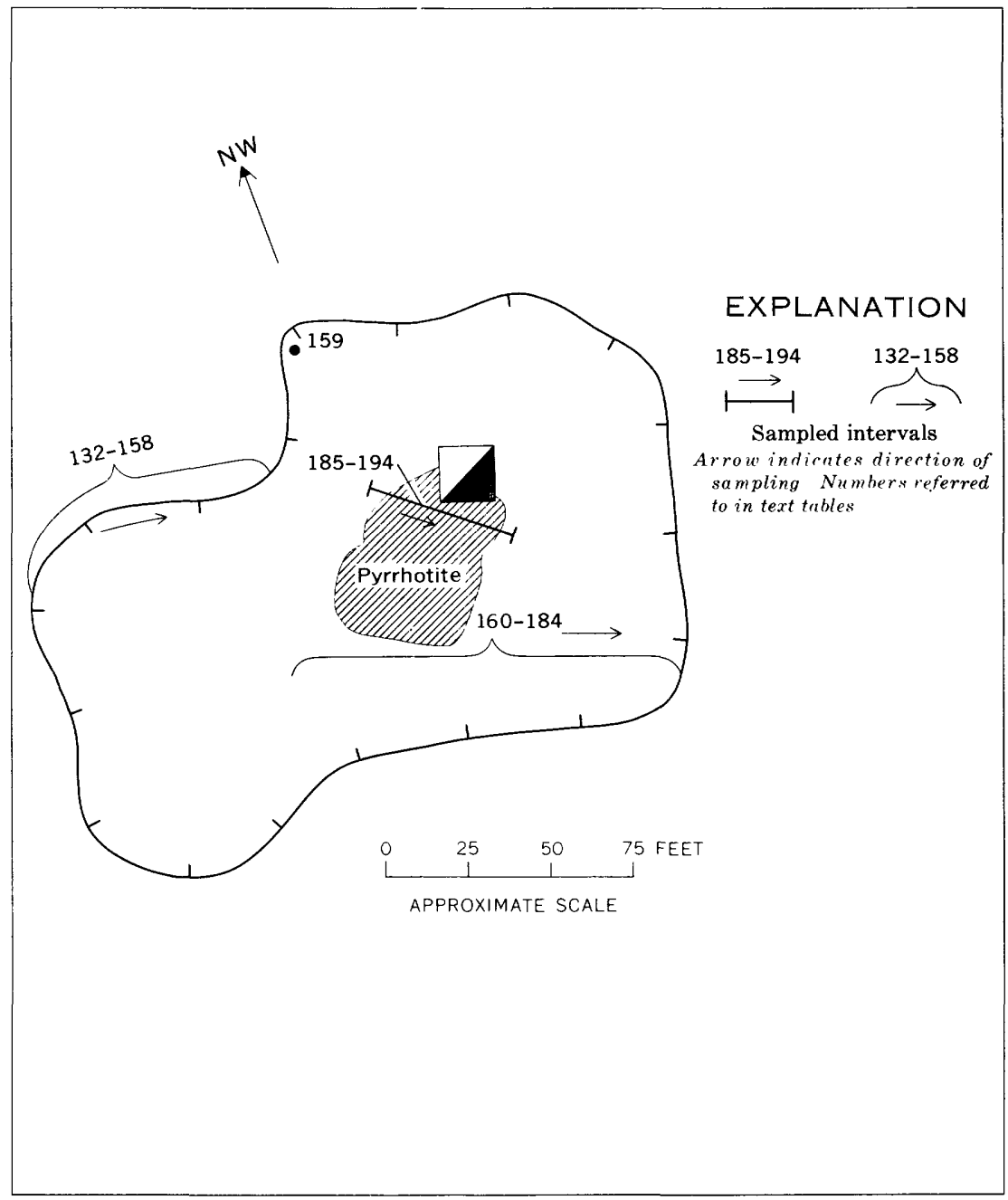

FIGURE 4. - Sample localities in Golden West open pit in Rochford Formation (see table 5).

\section{KING OF THE WEST MINE}

The King of the West mine is in the NW1/4 sec. 33, T. 2 N., R. $3 \mathrm{E}$. Allsman (1940) described the history of the mine from a 1937 report by the mine manager, Mr. Clifford L. Curran. Explorations apparently began in 1900 and continued sporadically until 1936. At present there are a few small opencuts, a shaft said to be 150 feet deep having 225 feet of drifts, numerous test pits, and an abandoned millsite. According to the record, in one of the opencuts there was a second shaft having minor lateral 
workings at the bottom. The workings are in chert-grunerite of the Rochford Formation, interpreted as having been folded into an overturned anticline, both limbs of which dip about $70^{\circ} \mathrm{E}$. Minor folds seen in the opencuts plunge northward, and the ore reportedly occurs in the apex of the pitching fold. According to Allsman (p. 114), sampling in one of the opencuts delineated an ore shoot about 30 feet wide, assaying $\$ 9.17$ in gold per ton (at $\$ 35.00$ per ounce). Other shoots discovered on the 75 -foot level of the deep shaft are reportedly 16 by 134 feet and 9 by 70 feet and assay $\$ 9.36$ and $\$ 11.98$ in gold per ton, respectively.

The reported tenor would seem to be verified by the 1935-36 production record of the North Star Mining Co., given below (Allsman, 1940) :

\begin{tabular}{lcccc}
\hline Year & $\begin{array}{c}\text { Ore milled } \\
\text { (tons) }\end{array}$ & $\begin{array}{c}\text { Value per ton } \\
\text { of gold head }\end{array}$ & Gross value & $\begin{array}{c}\text { Recovered } \\
\text { value }\end{array}$ \\
\hline $1935 \ldots \ldots \ldots \ldots .4,046$ & $\$ 7.14$ & $\$ 28,900.13$ & $\$ 9,817.37$ \\
$1936 \ldots \ldots \ldots \ldots . .2,944.4$ & 8.58 & $25,275.66$ & $13,074.98$ \\
\hline
\end{tabular}

The very poor recovery indicated above, said to be caused by inadequate equipment and thus too little time in contact with the cyanide, was responsible for the mine closure at the end of 1936 . The tonnages reported for 1935-36 indicate that the ore shoots discovered on the 75 -foot level of the mine were probably mostly mined out before the mine was closed.

The belt of Rochford Formation at the King of the West mine is about 2,000 feet long; the south end is truncated by a fault, and the north end most likely ends in minor folds, or a single faulted fold. Past experience shows that surface exploration gives no indication of the presence of an ore shoot at depth and that ore shoots are easily missed by holes bored at an angle westward from the east side of the formation. For best results, drill holes should commence in the center of the formation and proceed down the $60^{\circ}-70^{\circ} \mathrm{E}$. dip or should start on the east edge of the formation and go down vertically. According to the record, nearly 1,000 feet of Rochford Formation south of the main shaft has not been explored and should be, as should the 500-1,000 feet of formation north of the opencut. The structure of this north area could probably be defined with as few as half a dozen short holes (less than 100 feet), and, with luck, one or more locations for deep exploration might be found. Table 6 shows analyses of samples from a small open pit just north of the shaft.

\section{YELLOW BIRD MINE}

The Yellow Bird mine is near the southwest corner of sec. 28, T. 2 N., R. 3 E., about 700 feet northwest of the King of the West mine. Although discovered in the early days of the Rochford district, it has been idle since initial exploration. Some activity 
is reported for 1898 and some in 1938. Unofficial records indicate that $\$ 36,000$ in gold was produced during an early period, when two shafts and minor drifts and stopes were dug. In 1938, some development work was done, and a 50-ton flotation mill was built to mill oxidized ore, but the mill ran only a few days, and the mining company was dissolved in 1939 (U.S. Bur. Mines, 1954, p. 112). The ore is said to be in a northeast-trending shear zone 15 feet wide. As the map (pl. 1) shows, the shaft is in the Rochford Formation, near the junction of the east-dipping limb of a small anticline. Because exposures in the vicinity of the shaft are poor, the geology can be interpreted in various ways. Evidence of the northeast-trending shear zone was not found; however, there is no reason to believe that it is not present. It is easy to imagine a split from the inferred fault which lies east of the Yellow Bird shaft and passes through the shaft site. On the other hand, it has been amply proved by now that shearing is not essential to mineralization in the Rochford Formation and on this basis it would seem logical to assume that the type of mineralization in the Yellow Bird mine is about the same as that in the neighboring mines in the same formation - that is, impregnations and replacements in the chert-grunerite rock. And the discovery of ore shoots at depth in the King of the West mine could be repeated any place on this anticlinal belt of Rochford Formation. Therefore, despite the extensive test pitting on this belt, around the Yellow Bird and elsewhere, it should not be assumed that the formation is barren without prior deep testing.

TABLE 6. - Chemical analyses, in parts per million, of samples from King of the West mine

\begin{tabular}{|c|c|c|c|c|c|}
\hline Sample & $\mathbf{A g}$ & As & Sample $\quad \mathbf{A u}$ & $\mathbf{A g}$ & As \\
\hline 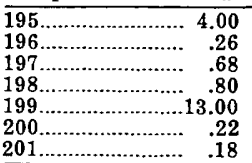 & $\begin{array}{l}1.5 \\
3.0 \\
2.0 \\
.5 \\
.5 \\
.5 \\
.5\end{array}$ & $\begin{array}{r}200 \\
2,000 \\
2,000 \\
200 \\
300 \\
160 \\
80\end{array}$ & 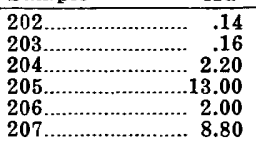 & $\begin{array}{r}<.5 \\
<.5 \\
.5 \\
.5 \\
1.5 \\
.5\end{array}$ & $\begin{array}{r}60 \\
60 \\
160 \\
160 \\
1,200 \\
40\end{array}$ \\
\hline
\end{tabular}

\section{DIVIDE LODE MINE}

The Divide Lode mine is in the NW1/4 sec. 32 and the $\mathrm{SW} 1 / 4$ sec. 29 , T. 2 N., R. 3 E. The claims were apparently staked about the turn of the century, and exploration work continued to 1905 (U.S. Bur. Mines, 1954, p. 117). There are numerous pits and at least two shafts. One of the shafts, probably that shown on plate 1 in sec. 32, is reportedly 140 feet deep; although its collar is in hanging-wall slates, the shaft probably intersects the east-dipping Rochford Formation at depth. Nothing is known about the grade of ore. Three samples of Rochford Formation collected.during 
this survey contained less than 1 part per million gold. Exploration suggestions made for other segments of this Rochford Formation belt apply equally well to the Divide Lode area. The wishbone bend in the Rochford Formation north of the Divide Lode should be examined, as should the inferred wishbone bend to the south (pl. 1, dashed line). A positive magnetic anomaly which crests over the southern wishbone bend, according to an unpublished aeromagnetic map by the U.S. Geological Survey, could be better defined by ground magnetometer and, if pyrrhotite is the cause, might be worth exploring. The aeromagnetic survey indicates that this structure plunges southeast at a low angle.

\section{BLACK TUNNEL MINE}

The Black Tunnel mine, in the SE $1 / 4$ sec. 32 , T. 2 N., R. 3 E., is a single adit which has a dump of pyritic, graphitic schist. The adit, whose length is unknown, could have penetrated the graphitic schist that underlies the apparently anticlinal Rochford Formation uphill and northeast of the tunnel. There is no record of production from this mine.

\section{MARY BELLE MINE}

The Mary Belle mine, whose development began in 1900 and ended in 1904 (U.S. Bur. Mines, 1954), is in the SE1/4 NW1/4. sec. 23, T. 2 N., R. 3 E., south of the Chicago, Burlington \& Quincy Railroad tracks. Gold reportedly occurs in a shear zone, and the property was once noted for its native gold specimens. Arsenopyrite, pyrite, pyrrhotite, chalcopyrite, grunerite, quartz, carbonate, biotite, and garnet have been reported. This property is of particular interest because it rests on one of the major anticlinal folds of the district. Exploration here appears to have been on the east limb of the middle of the three anticlines where there is a small opencut in the footwall graphitic schist near the base of the hill slope and a small tunnel near the top of the hill but topographically below the Rochford Formation. Aside from the reference to native gold specimens, the results of these explorations are unknown; however, the fact that this plunging anticline is gold bearing is important. Any ore zones in this structure will doubtless plunge southeastward with the structure. The hillside tunneling very likely crossed an ore zone, but there is no indication of exploration down the plunge. The enormous volume of Rochford Formation across the several folds in this area would seem to justify extensive exploration.

\section{MINES IN THE MONTANA MINE FORMATION}

The Montana Mine Formation, like the Rochford, consists of chert-grunerite rock, and the mineralization is by impregnation or 
replacement by sulfides, mainly pyrrhotite, arsenopyrite, and pyrite. As in most of this district, the gold is probably closely associated with the arsenopyrite. There are two inactive mines in this formation and dozens of unnamed prospects. Both of the inactive mines occur near plunging anticlines; however, despite considerable development, the anticlinal crests, which very likely represent plunging ore shoots, have not been mined.

\section{MONTANA MINE}

The Montana mine is in the central and south-central part of sec. 3, T. 2 N., R. 3 E. According to Allsman (1940), development began near the center of section 3 and moved in about 1901 to the south-central location, where development continued for 2 or 3 years. The mine was idle from 1906 to 1936 and was cleaned out and examined in 1936. Minor activity continued after 1936, but at present the mine is inactive, and all buildings and equipment have been removed from the property.

The remains of the old workings in the center of sec. 3 include a short hillside opencut, which probably leads to an adit having a caved portal, and a small glory hole, probably originally connected to the adit. Both adit and glory hole are in the chertgrunerite rock, which at this point shows a minor drag fold that plunges about $40^{\circ} \mathrm{SE}$. Graphitic hanging-wall schists occur on the west side of the workings, and gray footwall slates are on the east side. According to Allsman, unoxidized sulfide ore was mined and was not suitable for amalgamation. Three grab samples were collected here during the present survey; the best, from the opencut in front of the adit, assayed $\$ 3.40$ in gold per ton.

The workings to the south reportedly consist of a vertical shaft 101 feet deep having 444 feet of lateral workings at the bottom, a 25-foot drift on the 60-foot level, and a 435-foot adit which joins the shaft, probably around the 60-foot level, and a 435 -foot adit which joins the shaft, probably around the 60-foot level. An opencut at the adit portal shows a synclinal structure in the chertgrunerite rock. The shaft collar is in hanging-wall graphitic schist, which is apparently in the same syncline as that seen at the adit portal. Immediately west of the shaft is a south-plunging chert-grunerite anticline which has a wraparound of hanging-wall graphitic schist on the south side. Both limbs of this anticline appear to dip about $70-75^{\circ} \mathrm{E}$. The outcrop is poor, and the direction and degree of plunge are uncertain; however, the plunge must be $60^{\circ} \mathrm{SE}$. or less. This anticline-syncline couple seems to be cut off by a north-trending fault, which must be near the east side of the shaft. The syncline near the adit is apparently truncated by the fault and juxtaposed to the footwall slates. The 
total structure, as here interpreted, indicates that the shaft is probably entirely in graphitic schists. Five bands of quartz-grunerite were observed in the shaft, adit, and connecting workings (Allsman, 1940, p. 121). Two of the bands reportedly contained sulfide gold ore assaying $\$ 6.00$ in gold per ton, and a third band assayed $\$ 2.80$ in gold per ton. Sampling during the present survey was restricted mostly to the hilltop crown of the anticline, which lies west of the shaft. Free gold can be panned from the dirt and rock on this hill, and six grab samples of rock from the southernmost outcrop (crest of the anticline), analyzed by atomic absorption and by fire assay, gave values of $\$ 3.40-\$ 15.00$ in gold per ton.

Sample localities from north of the anticlinal crest are shown on figure 5. See table 7 for analyses.

\begin{tabular}{|c|c|c|c|c|}
\hline Sample & $\mathrm{Au}$ & Ag & $\mathrm{Cu}$ & As \\
\hline RB-218-69 & $9 \ldots \ldots \ldots \ldots .0 .40$ & 1.00 & 210 & 60 \\
\hline 219 & ……....... & .80 & 98 & \\
\hline & …….... .20 & .60 & 110 & 300 \\
\hline 221 & …........ 8.00 & .60 & 160 & 800 \\
\hline & …….......... 20 & .20 & 58 & 100 \\
\hline 223 & …….......... .04 & .80 & 27 & 200 \\
\hline 224 & ............. .14 & .80 & 23 & 100 \\
\hline 225 & …-....... 3.80 & 1.00 & 17 & 1,000 \\
\hline 226 & ...........4. 40 & 1.00 & 110 & 1,50 \\
\hline 227 & ….... 6.00 & 1.00 & 57 & 1,400 \\
\hline 228 & ………... .90 & .60 & 28 & 1,100 \\
\hline 229 & ………. . 70 & 1.00 & 65 & 1,500 \\
\hline 230 & ……........ .50 & .80 & 31 & 1,500 \\
\hline 231 & 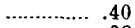 & & 27 & 900 \\
\hline 232 & ………... 08 & 1.00 & 120 & 1,000 \\
\hline
\end{tabular}

The surface rock is oxidized, and no sulfides were seen; however, it is assumed that the mineralization is pyrite-arsenopyrite-gold, that of the other parts of the property. On the basis of what is already known about gold occurrence in this district, it would seem that the ore in the crest of this small anticline almost certainly continues down the plunge as an ore shoot. The projected ore shoot, probably truncated on the fault to the east at a depth of 300-500 feet, might be recovered by drifting south along the footwall, but this is highly speculative. Whatever the eventual findings, a need for further detailed exploration of the anticline is indicated.

\section{MONTEZUMA MINE}

The Montezuma mine is in the NE1/4 sec. 14 , T. 2 N., R. $3 \mathrm{E}$. The early history of this mine is incomplete. Discovered about 1895 , the mine workings reportedly included three adits (one over $600 \mathrm{ft}$ long) and a 60-foot shaft by 1899. The mine operated intermittently, under several different owners, until about 1911 (Allsman, 1940, p. 113). The ore was milled and amalgamated at Rochford, but there is no production record. This mine is in 
the Montana Mine Formation belt of chert-grunerite rock, the two segments of which are separated by an inferred fault. The west segment is cut by numerous large hillside pits. Near the south end of this segment, in a little gulch, there is a cut in brecciated greenstone which apparently is the caved portal to the 600-foot adit mentioned above. The adit apparently trended due north in the fault zone. The east segment of chert-grunerite rock is separated from the west segment by the fault, which includes an area of footwall slates (Irish Gulch). This east segment is part of a small anticlinal fold that plunges southeastward. Diagonally across the crest of the fold is a small opencut. The crest or crown of the fold shows irregular patches of vein quartz and disseminated pyrite. Several samples of crown rock collected during this survey assayed $\$ 6.20-\$ 10.00$ in gold per ton. Apparently, this particular "ore" shoot was never explored. The little anticline should plunge southeastward and probably continues to great depth. Whether the mineralization follows the plunging crest remains to be determined.

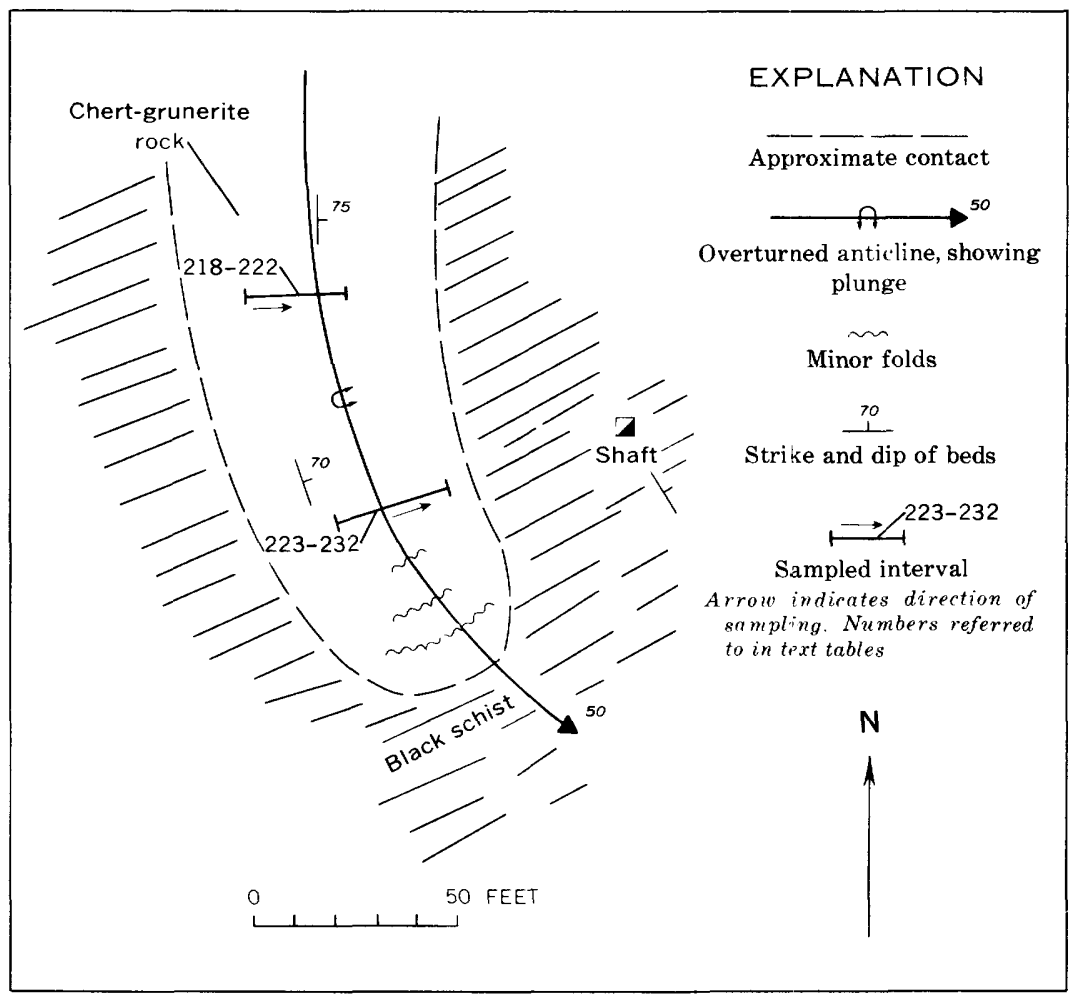

Figure 5. - Sample localities on Montana mine anticline. 


\section{OTHER PROSPECTS OF INTEREST}

Because of the great mass of Rochford Formation in the anticline in the SE1/4 sec. 15, T. 2 N., R. 3 E. and because rocks exposed near the footwall contact of the Rochford Formation contain as much as 1.7 parts per million gold, this anticline is considered a prime target for exploration by drilling.

In the SE $1 / 4$ sec. 12 , T. 1 N., R. 3 E. $(1,300 \mathrm{ft}$ north and 300 $\mathrm{ft}$ west of SE. cor.), there is a single test pit on a 12 -foot wide quartz vein of considerable interest. The vein is heavily impregnated with arsenopyrite and is gold bearing. Sample values, in parts per million, are as follows:

\begin{tabular}{|c|c|c|c|c|}
\hline Sample & $\mathrm{Au}$ & $\mathbf{A g}$ & $\mathrm{Cu}$ & As \\
\hline \multicolumn{5}{|c|}{ Dump samples, quartz sulfides } \\
\hline $\begin{array}{c}\mathrm{RB}-239-69 \\
240 \\
241 \\
242 \\
\end{array}$ & 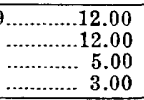 & $\begin{array}{r}0.20 \\
.20 \\
\ldots \\
.20 \\
\end{array}$ & $\begin{array}{l}42 \\
22 \\
15 \\
15 \\
\end{array}$ & $\begin{array}{r}>50,000 \\
25,000 \\
50,000 \\
35,000 \\
\end{array}$ \\
\hline \multicolumn{5}{|c|}{ Selvage schist, east side of pit } \\
\hline 243 & $\ldots \ldots \ldots \ldots . . . . .0 .20$ & 0.60 & 50 & 25,000 \\
\hline \multicolumn{5}{|c|}{ Selvage schist, west side of pit } \\
\hline $\begin{array}{l}244 \\
246\end{array}$ & 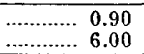 & $\begin{array}{r}0.60 \\
.80\end{array}$ & $\begin{array}{l}50 \\
69\end{array}$ & $\begin{array}{r}25,000 \\
>50,000\end{array}$ \\
\hline \multicolumn{5}{|c|}{ Vein quartz in schist, west side of pit } \\
\hline 245 & 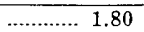 & 0.20 & 36 & 800 \\
\hline
\end{tabular}

\section{REFERENCES CITED}

Allsman, P. T., 1940, Reconnaissance of gold-mining districts in the Black Hills, South Dakota: U.S. Bur. Mines Bull. 427, $142 \mathrm{p}$.

Bayley, R. W., 1970, Structure and mineralization of Precambrian rocks in the Galena-Roubaix district, Black Hills, South Dakota: U.S. Geol. Survey Bull. 1312-E, p. E1-E15.

Darton, N. H., and Paige, Sidney, 1925, Description of the central Black Hills, South Dakota: U.S. Geol. Survey Geol. Atlas, Folio 219.

Dodge, T. A., 1942, Amphibolites of the Lead area, northern Black Hills, South Dakota: Geol. Soc. America Bull., v. 53, no. 4, p. 561-583.

Harder, J. O., 1934, Geology of a pre-Cambrian area at Rochford and its relation to regional structure of the northern Black Hills: Lead, S. Dak., South Dakota State School of Mines, unpub. Engineer of Mines thesis, $51 \mathrm{p}$.

Hosted, J. O., and Wright, L. B., 1923, Geology of the Homestake ore bodies and the Lead area of South Dakota: Eng. and Mining Jour., v. 115, no. 18 , p. $793-799$, no. 19 , p. 836-843.

Noble, J. A., and Harder, J. O., 1948, Stratigraphy and metamorphism in a part of the northern Black Hills and the Homestake mine, Lead, South Dakota: Geol. Soc. America Bull., v. 59, no. 9, p. 941-975.

Slaughter, A. L., 1968, The Homestake mine, in Ridge, J. D., ed., Ore deposits of the United States, 1933-1967 [Graton-Sales volume]: New York, Am. Inst. Mining, Metall., and Petroleum Engineers, Inc., v. 2, p. 1436-1459.

U.S. Bureau of Mines, 1954, Black Hills mineral atlas, South Dakota, Part 1: U.S. Bur. Mines Inf. Circ. 7688, 123 p.

Zartman, R. E., and Stern, T. W., 1967, Isotopic age and geologic relationships of the Little Elk Granite, northern Black Hills, South Dakota, in Geological Survey research 1967: U.S. Geol. Survey Prof. Paper 575-D, p. D157-D163. 